\title{
The Learning Model of Happiness through French Literature Appreciation
}

\author{
Mohamad Syaefudin \\ Universitas Negeri Semarang, \\ Indonesia \\ Email: \\ m_syaefudin@mail.unnes.ac.id
}

\author{
Emzir Emzir \\ Universitas Negeri Jakarta, \\ Indonesia \\ Email: emzir.unj@unj.ac.id
}

\author{
Ninuk Lustyantie \\ Universitas Negeri Jakarta, \\ Indonesia \\ Email: \\ ninuk.lustyantie@unj.ac.id
}

Received: 20 December 2017. Revised: 21 February 2018. Accepted: 10 April 2018

\begin{abstract}
This study aims to (1) develop learning models of happiness in learning French through literary works, and (2) to describe the application of learning models of happiness in learning French through literary works. The study applied a qualitative approach with two designs in exploratory research (1) to produce a learning model of happiness and (2) action research to evaluate the implementation of the learning model in the field. Data collection techniques are conducted through (1) in-depth interviews with French experts, (2) literary experts; and (3) psychologists to gain an important point of learning happiness. Then from the results of in-depth interview was compiled draft learning model of happiness through focus group discussion This research was conducted at Universitas Negeri Semarang, with research time from March to October 2017.The results of this research are the model of happiness teaching with ASSURE model which includes analyzing the students, formulating specific learning objectives, choosing methods, media, and teaching materials, utilizing media and teaching materials, requesting student response, and evaluation.
\end{abstract}

Keywords: Teaching, happiness, literature, French

How to Cite: Syaefudin, M., Emzir, E., \& Lustyantie, N. (2018). The Learning model of happiness through Frenchliterature appreciation. Language Circle: Journal of Language and Literature, 12(2), 143-152.

\section{Introduction}

Foreign language learning through the media of literature appreciation has been widely done, however, there are less researchers or teachers who attempt to implement the newest knowledge to the learning process. Most of the literature appreciation sees literary works from the perspective of the work itself. Citing from Fananie (2001, p.63), there are elements in the literary works, namely the intrinsic and extrinsic elements. The intrinsic element sees a literary work from the perspectives of elements which build it, such as: the social condition of the society, the philosophical thoughts, as well as various forms of human psychological phenomena. The second aspect has not been explored much, especially when it is related to the newest discovery of science.

Relating the foreign language learning with the learning of happiness is considered as a breakthrough since it brings the literary work closer to the other developed social science knowledge which is the positive psychology. The reason behind the idea of relating the learning of happiness with the positive psychology is because the idea of 
seeking for happiness has been done since the era of ancient Greek through the idea of Aristoteles and Plato which has been widely discussed and proven to be relevant to be done even up to this millenial era. When modern society is suffered from any forms of social problems, higher demands of life, as well as inside and outside pressure, then one will start to think whether they are happy with his life.

Then, when it is seen from the educational perspective, happiness is usually far from the field. Whereas, the trully aim of education should be giving significant contribution towards individual and communal happiness.

In order for the learning of happiness to be accepted easily, a media that is able to bring the message of happiness is needed, which is supposed to be free from the impression of teaching or lecturing. Therefore, literary work as a form of message conveyer is considered to be effective in bringing the message since it has the power of persuasing, from the ability of the author to illustrate the persuasiveness through the interesting characters and plot which build the story. In the end, the reader can understand the meaning of happiness seeking and is hoped to be able to change the perception of happiness.

Layard (2007) delivers the idea that the world of education has to be able to have the new teacher figure who is trained to teach value and ways to achieve happiness. It is in line with the idea which was also delivered by Rijavec (2014) who states that to teach happiness at school, it can be based on variety of reasons, such as (1) the high level of depression among youngsters from all over the world; (2) the tendency of life satisfaction degradassion during the half end of this century; (3) the low student satisfication towards school services in many countries.

Furthermore, Rijavec also gives the example of Positive Education Model as the main source of learning model of happiness as part of the implementation of positive psychology as one of the school's thorough appoach which six main targets of happiness are made, including, positive emotion, positive involvement, positive achievement, positive aim, positive relationship, as well as positive health with the focus lays upon the character power.

Thus, we can assume that learning of happiness is relatively relevant to be given to students with the problems listed above. However, all the time, the learning model of happiness hasnot been developed in Indonesia yet, especially in teaching foreign language through literature appreciation.

Since the learning of happiness approach through literature has not been implemented in the French Study Program at Universitas Negeri Semarang (abbreviation: UNNES) yet, therefore, it is considered to be needed to form a learning model of happiness through French literature appreciation.

The literary work chosen as the learning media of happiness in this study is a novel entitled l'homme qui voulait être heureuxor A Man who Wants to be Happy by Laurent Gounelle. This novel tells about a French man who learns about wisdom from Balinesse people to understand the meaning of life happiness. It is packed with the knowledge of psychology and moral value through an interesting plot and is possible to be used as the learning media of happiness.

This novel is chosen by researcher as a piece to be studied in this study because of several reasons. First, seeing from the title, l'homme qui voulait être heureux, implicitly tells about the journey of happiness seeking. 
The sentence used in the title of the literary work means 'hope' in French, or the willingness to achieve happiness. Second, the novel which was firstly published in 2008 received the best selling achievement of the year and was translated into 25 different languages. Third, it is rare to find a French novel which tells about contemporary Indonesian people after the "une saison indonésienne" by Jean Rocher (2000). Apart from these two novels which tell about Indonesian people, other French novels usually tell about French's neighbourhood. It makes finding un homme qui voulait être heureuxto be exciting and promising since it is relevant to the place where researchers see the perspectives from.

In addition to this, reading and analyzing meaning towards the idea of happiness seeking in a novel as part of positive psychology needs to be done to reveal how human has developed themselves in order to find the meaning of life.

By inserting literature into the learning, it means that students are asked to be involved into the thinking of social and humanitarian problems. Reading literary works allows one to gain inputs on humanity and society, so that in the same time, it will trigger the motivation to act out for the betterment of both humanity and society (Djojosuroto, 2006, p.87).

Besides, with the knowledge acquired by the students, they might gain pleasure and intellectuality from the literaty work. The need of aesthetical meaning seeking and the intellectual meaning will correlate positively with the students' need in developing the intellectual and emotional maturity. Therefore, literature can act as a means of meaning digging if it is correctly taught.
Through the literature learning, students of French Study Department of UNNES are expected to be able to find out the moral, educational, aesthetical, and social values, as well as other benefits which are educational from the France culture or broader from Francophonie. Besides, based on the aim of Introduction to French Course in Indonesia, the teaching of French literature in University is supposed to be realized in a proper and correct way, so it might bring benefits to the students, especially in adding new knowledge, new experience, and thoughts about life and being alive.

Nurgiyantoro mentions two types of novel, the serious and the popular. The serious type of novel is a kind of novel which is considered to be able to give insights of every possibility in life. It is the actual meaning of literature. In order to understand a serious literary work, high level of concentration is required which also supposed to be supported by the willingness to do so. Experience and problems of life which is shown in the serious type of novel is seen and revealed up to the core of the essence of life that is universal in nature. For the serious novel, besides it gives entertainment, it also implicitly gives the valuable experience to the readers or at least to invite readers to grasp and truly reflect the problems raised in the literature. On the other hand, the popular type of novel is a kind of novel which takes popular problems in its era and is highly demanded by society, especially teenagers and the youth. The popular type of novel shows actual and up to date problems. Popular novel does not show the problem of life intensively and not even attempt to analyze the essence of life deeply (Nurgiyantoro, 2006, pp.16-17). Seeing from the types of the novel, therefore, the novel 
entitled l'Homme qui voulait être heureux used in this study belongs to the novel that follows the flow of conciousness or the serious one.

Therefore, problems raised in the study are (1) how to develop the learning model of happiness in the French learning through French literature is, and (2) how to implement the learning model of happiness in French learning through literature is.

\section{Methodology}

This research applies the research designs of qualitative approach: (1) exploratory research to produce learning models of happiness and (2) action research to evaluate the implementation of the learning models in the field. Meanwhile, data collection technique is done through (1) deep interview with French language expert, (2) literature expert; and (3) psychology expert to gain the important point of learning models of happiness. Then, from the results of deep interview, learning models of happiness draft is arranged through focus group discussion by implementing learning models of ASSURE.

The ASSURE model has been invented by Heinich, et al. since 1980 and still being developed by Smaldino, et al. until now. The name of ASSURE model is not taken from the founder, but based on the first letter of model design steps, those are: Analyze Learner (analyzing students); State Objectives (formulating the specific learning goals); Selection of media on materials (choosing methods, media, and learning materials); Utilize media and materials (using media and learning materials); Require learner's response (asking for students' responses); Evaluate (Evaluation).

After the learning models were formulated, the researchers conducted the trial and error to the French Department Students,
Universitas Negeri Semarang (UNNES) to understand the implementation of the model during the learning process. This research was held in Universitas Negeri Semarang and Universitas Negeri Jakarta, from March 2017 to October 2017. Respondents that were involved in this research werethe French lecturers; psychology experts, and literature experts from Universitas Negeri Semarang, Universitas Negeri Jakarta, and Universiatas Gadjah Mada. This research also involved the students of French Department of Universitas Negeri Semarang.

\section{Results and Discussion \\ Results}

Every learning model design has different components from the other models. Therefore, component is an important aspect in a learning model design. The existing component draws aspects and activities that should be done in designing a learning process. Basic components used in learning model designs are:

\section{Learner or student}

Learner is the party that becomes the focus of a learning design. The most needed information to be found are their characteristics, initial ability or precondition. The third semester students of French Language Education who take Litérature Française module in Study Group 1 in the academic year of 2017/2018 are nine students.

\section{Learning objectives (general and specific)}

The formulation of learning is the explanation of competencies that are supposed to be mastered by the students if they have done and succeed in mastering certain learning materials. Learning objectives in big scope is considered as the general objectives, while the objectives that are achieved for specific skills 
that can be observed is considered as specific objectives.

\section{Learning analysis}

Learning analysis is the process of analyzing the topics or materials that will be learned. Topic analysis is related to the initial ability, if it is needed. Therefore, the learning media designer can predict the steps of their own material categories. Learning analysis is done to trace and anticipate the big obstacles such as level of difficulties or initial behavior that has not been mastered yet by the students.

\section{Learning strategies}

Learning strategy is an effort that is done by the designer to determine the message delivery technique the methods and media, the flow of learning content, and the interaction between lecturers and students. Learning strategy can be developed in macro or micro learning strategy. Macro learning strategy is a strategy which is applied in one year or one semester period. Meanwhile, micro learning strategy is developed for one teaching and learning activity (one meeting). Learning strategy is done through: (1) media utilization, (2) media selection, (3) time allocation, and (4) interviewee allocation.

\section{Learning materials}

Learning material is a material format that is given to the students. The format can be related to the specific media, handouts or text books, games, and other things.

\section{Learning assessment}

Learning assessment is related to the measurement of ability and competence that has been mastered or not yet mastered by the students. The assessment is not only related to some specific numbers as a learning result which shows the learning achievement, but also an input for the designers and lecturers to understand what factors influence the success or failure of the learners' achievement.

1) Oral assessmentin the form of questions and answers during the learning process.

2) Written assessment through questions presented in the assignment.

The assessment in learning of happiness materials through literature appreciation is done through the verbal questions to check the language ability of the students. Further, the assessment is given after the materials are completely given to the students with the questions related to the identity of literature, the content, the message from the author (moral value), and the students' reflection towards the idea of the happiness seeking.

\section{Discussion}

Skills expected to be acquired by the students after attending the French literature course are:

1) Having the knowledge about categories and characteristics of French Literature

2) Having the knowledge about famous French literature works and its authors

3) Having the ability to understand the simple French literature works

4) Having the knowledge about categories and characteristics of Francophonie literature

5) Having the knowledge about famous Francophonie literature, its authors, and its origin

6) Having the ability to understand the contents of simple Francophonie literature.

Before the six components in learning of happiness are explained, Semester Plan is presented in the following. It is taken from French literature module of French Education 
LANGUAGE CIRCLE: Journal of Language and Literature, 12(2) April 2018

Study Program in Universitas Negeri Semarang.

\begin{tabular}{|c|c|c|c|c|c|c|c|}
\hline \multicolumn{2}{|c|}{$\begin{array}{l}\text { Lourse: } \\
\text { Littérature française et Francophone }\end{array}$} & Semester: 3 & \multicolumn{2}{|l|}{ Credit: 2} & \multicolumn{3}{|c|}{ Code: $15 \mathrm{P} 01045$} \\
\hline \multicolumn{2}{|c|}{ Study Program: French Education } & \multicolumn{6}{|c|}{ Lecturer: Novi Kurniawati } \\
\hline \multicolumn{2}{|c|}{ Learner Goals } & \multicolumn{6}{|c|}{$\begin{array}{l}\text { 1. Actively act as a proud citizen who love their own homeland, having nasionalism as well as responsibility } \\
\text { towards their country and nation; } \\
\text { 2. Respecting cultural diversity, perspectives, religions, and beliefs, as well as opinions and other's original } \\
\text { discovery; } \\
\text { 3. Implementing knowledge in the field of language, social, and cross-culture. } \\
\text { 4. Mastering the concepts of French Literature ad Francophonie. }\end{array}$} \\
\hline \multicolumn{2}{|c|}{ Course Objectives } & \multicolumn{6}{|c|}{$\begin{array}{l}\text { After attending the course, the students are expected to master the knowledge of categories and characteristics of } \\
\text { French literature and Francophonie, as well as understand the well-known and simple literaty works of French and } \\
\text { Francophonie along with the authors of the work. }\end{array}$} \\
\hline \multicolumn{2}{|c|}{ Course Description } & \multicolumn{6}{|c|}{$\begin{array}{l}\text { This course teaches knowledge about categories and characteristics of French and Francophonie literature as well } \\
\text { as to find out the well known literary works of French and Francophonie along with its authors. }\end{array}$} \\
\hline Week & The Expected Competence & Learning Materials & $\begin{array}{l}\text { Learning } \\
\text { Method }\end{array}$ & $\begin{array}{c}\text { Time } \\
\text { Allotment }\end{array}$ & Evaluation & Criteria/ Indicator & $\begin{array}{l}\text { Percent } \\
\text { age }\end{array}$ \\
\hline 1 & 2 & 3 & 4 & 5 & 6 & 7 & 8 \\
\hline $1-2$ & $\begin{array}{l}\text { Acquiring the knowledge of } \\
\text { category and characteristics } \\
\text { of French Literature }\end{array}$ & $\begin{array}{l}\text { - Defintion and the Littérature } \\
\text { française coverage } \\
\text { - Classification of Littérature française } \\
\text { - Littérature classique } \\
\text { - Littérature moderne }\end{array}$ & $\begin{array}{l}\text { - Lecturing } \\
\text { - Presentation } \\
\text { - Question and } \\
\text { Answer } \\
\text { - Assignment }\end{array}$ & $\begin{array}{l}2 \times 110 \\
\text { minutes }\end{array}$ & $\begin{array}{l}\text { - Oral } \\
\text { assessment } \\
\text { in the form } \\
\text { of Question } \\
\text { and Answer } \\
\text { during the } \\
\text { learning } \\
\text { process } \\
\text {-Written } \\
\text { assessment } \\
\text { through }\end{array}$ & $\begin{array}{l}\text { - Able to } \\
\text { understand and } \\
\text { answer } \\
\text { questions } \\
\text { related to the } \\
\text { definition, } \\
\text { coverage, and } \\
\text { classification of } \\
\text { French } \\
\text { literature } \\
\text { - Able to have } \\
\text { the skills in } \\
\text { using ICT to } \\
\text { underdtand } \\
\text { information and }\end{array}$ & $15 \%$ \\
\hline
\end{tabular}

Figure 1 The Semester Plan of French Literature Modul of French Education Study Program of Universitas Negeri Semarang

\section{Learners or students}

The practice or implementation of learning of happiness is given to the students in the third semester of French Education Study Program who take Littérature Française module as one of their course. The students belong to study group 1 who consist of 5 students who have mastered French competence which unable them understand the basic French language. Therefore, the students can follow the course.

\section{Learning objectives (general and specific)}

In general, learning objectives of learning of happiness are to find out the happiness concept in literature works. Moreover, students are able to mention the happiness elements of the character, ways to achieve that happiness, and reflection towards the learner itself. It is expected that after learning about this topic, the students can find the essence of happiness that is told by the author in the literary works. The story then becomes theaspect of comparison for the students' real condition in searching and 
fighting for the happiness in their real life compared to

\section{Learning analysis}

Learning literature appreciation in French Education Study Program is given limitedly. It only covers two credits in the third semester. Therefore, the literature appreciation course here is only given as an introduction. There are theme classifications in the material, such as the French literature in the middle century, the $16^{\text {th }}$ centuries, and the contemporary literature, as well as francophonie literature that is created by the authors from outside Europe, usually from Africa, in French. This happiness theme can be added to the French contemporary prose literature appreciation. Therefore, it has a correlation with the current life.

Learning of happiness is an effort in connecting the learning of literature with the psychology study. Happiness becomes one of the specific studies in the psychology world. Introducing the students to this field can give them more actual knowledge perspectives. Besides, connecting the learning to learner's psychological problem adds more value to the meaningfulness in the higher education. Through the literature appreciation in French literature module, students are invited to see the problem of life and searching for the solution through literature appreciation of the ceritain figure's journey in gaining the happiness.

\section{Learning strategies}

To teach the happiness theme, one should first decide the delivery method through lecture, that is by telling the story sequences which illustrate happiness as the theme.The researchers select a French novel entitled l'Homme qui voulaitêtreheureuxby Laurent
Gounelle as an example of literature appreciation that contains the message of happiness seeking. The learning process is started by asking about the cover of the novel and trying to dig up what is in the novel's cover. The questions delivered to the students are about what the title of the novel is, what the meaning of the titleis, who the writeris, when the novel publishedis, and where the setting of that novelis. The illustration of the cover can also be explored as the course' initial depth learning: what kind of the illustration that is being used, why it uses specific colours, and so on,in order to build the presumption about the new material that is being taught.

The lecturer then opens the first page, ask the students to read one paragraph and ask the others to translate, while the others also are also asked to check the meaning accuracy. After finishing the first round, the lecturer explains meaning and implication of the sentences that is being read by the students related to the theme. Lecturer then continues with the main idea of the novel while sometimes ask the students to check the specific pages. The choice of page is also initially selected based on the author's idea about happiness that wants to be delivered by the lecturer. In revealing the meaning of the character, sometimes, more explanation is needed, considering that: 1) some expressions used are quite complicated to be understood fast, therefore, it needs to be read many times. 2) The difference of point of view in placing the specific idea as a happiness marker that maybe not common to be felt by the reader from the different social background. Therefore, the lecturer gives more times to students to find this kind of findings.

\section{Learning materials}


The main learning material used is an original document in the form of novel entitled l'Homme qui voulait être heureux.

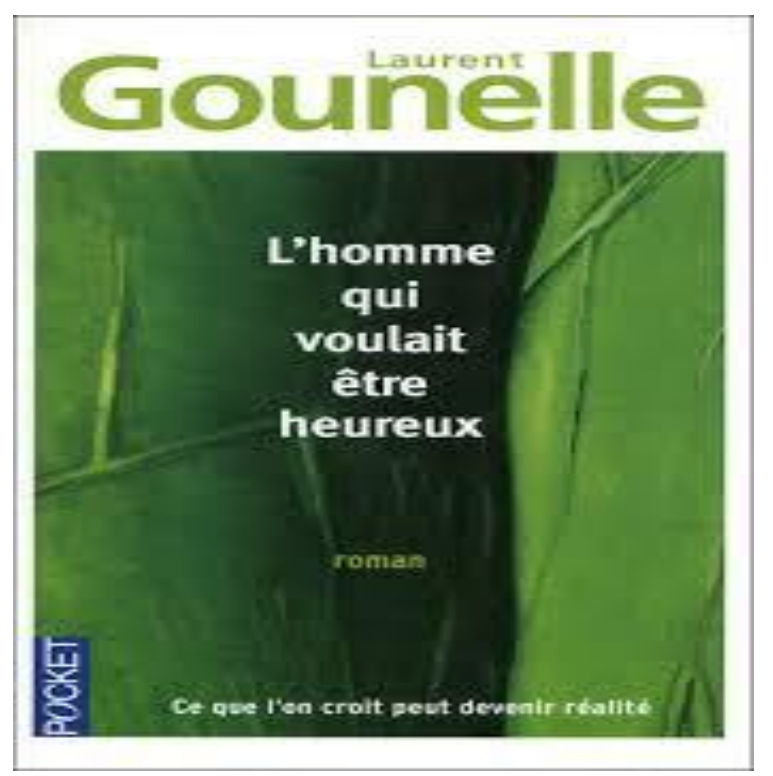

Figure 2 Cover of the Novel entitled l'Homme qui voulaitêtreheureuxby Laurent Gounelle

Besides, media of picture contains various people expression is also used to stimulate students' thought about various emotional perceptions and expressions. The media will then give more understanding towards various human emotions.

\section{Learning Assessment}

To understand the feedback of happiness learning, the researcher gives mini-test that consists of five questions about the content of the novel. The questions are about the theme, character, setting, time, and content of the literature. From five respondents who join the class, results show that all main components of the novel can be understood by the students.

First, question about the novel's theme. The respondents answer the happiness theme (HAS), the happiness seeking (DM), and the experience of happiness (FRM). Among all respondents, only one who gives the title of the novel as the answer. It means that respondent already understands the theme in the novel entitled l'Homme qui voulaitêtreheureux.

Second, question about two central characters in the story. All respondents can give the correct answers, they are Julian and Samtyang. Those characters are the dominant characters in the novel.

Third and fourth are questions about place and time settings. All respondents take Bali as the answer or more specific in Ubud, Bali area. It is indeed correct place where the author sets the location. For the time setting of the story, many respondents answer 2008 which is actually the wrong answer. 2008 is the publishing year of the novel. The novel itself is based on the creation of the author who visited Bali around the end of 90s, and kept writing the novel until it is published ten years later.

Fifth is question about the moral value that they found in the novel. The answers of respondent: 1) This novel tells about Indonesian's kindness from the perspective of French people (APL); (2) Do not see people just from their physical characteristics (HAS); (3) If we want to be happy, we have to always think positively (DM); (4) Happiness is a quality (IAK); (5) Happiness does not come easily, it needs to be searched (FRM).

Sixth is the respondents' opinion about the novel that is appreciated. Based on respondents, (1) The story gives pictures on how Indonesian is seen from the perspectives of foreigners visiting our country (APL); (2) The novel is a great novel since it teaches us on how to sacrifice to achieve happiness (HAS); (3) The story is great since it teaches us that happiness actually comes from our own selves (DM); (4) The story is able to 
motivate ourselves (IAK); (5) The story is good since it inspires us who are still seeking for happiness. By using Bali as the setting, that story also can indirectly promote Indonesia (FRM). Therefore, it can be seen that the assessment of all respondents towards l'Homme qui voulaitêtreheureux are positive. They appreciate the moral value and happiness seeking as parts of message intended to be delivered by the author.

Seventh, respondents receive lesson/ wisdom/ value from the novel. Those are: (1) "If we believe in something, then that believe will give the impact to ourselves." (APL).; (2) Do not judge someone just from his/her physical appearance, willing to sacrifice to get what you want (HAS); (3) Positive mindset will bring happiness; if we want to be happy, sacrifice should be made (DM); (4) In achieving the happiness we have to be willing to sacrifice something (IAK); and (5) In searching for happiness and interest, there are things that should be sacrificed (FRM).

Eighth is the opinion about the characteristic of happy people. Respondents assess that happy people are (1) able to finish their responsibility and achieve their goals (APL); (2) able to control their selves and their minds, so it can walk hand in hand, and create happiness to their selves and others (DM); (3) able to have determination that one can change from unable to be able (IAK); (4) able to think positively and ableto be always feel grateful upon what they have (FRM).

Ninth, self-assessment as a happy people, especially related to French learning in general or french literature in more specific context. Respondent claims that they are happy, because he is from Papua are able to be a student in French Education Study Program (APL); He is not happy since he is easy to forget and he finds many vocabularies need to be remembered during the course (HAS); Happy, because he can gain new knowledge that other people might never have. He also can give information to other people about what he has already learned during the time when he learns French (DM); $\mathrm{He}$ is a happy person because can learn French literature and learn about the habit of French people and the French's history that is different from the history of Indonesia and the habit had by Indonesian people. Moreover, he gets more knowledge (IAK); Yes, he feels happy (FRM).

Tenth is the condition that can make people happier, related to French learning. Respondents answer that they are happier (1) because they can be with people from other places in French Education study program and very happy because the lecturers are kind and amazing (APL); (2) direct communication practice with the native of French to make them able to understand the oral characteristics from the source (HAS); happiness that can make them happier by learning French is to be able to receive more beneficial knowledge, to receive grades, and to achieve better resultswhich keep improving every semester. Also, receiving the easiness in learning French (DM); they can share the knowledge with people surrounded them (IAK); achieving comfortable learning atmosphere which is not too serious but understandable; being able to practice (speaking) directly with the French native (FRM).

\section{Acknowledgement}

Sincere gratitude is sent to The Indonesian Ministry of Research, Technology, and Higher Education that has granted me with funding under the category of Disertation Grant in the year of 2017, and to all lecturers and students of French Education Study 
Program of UNNES, who have given us supports and kinds of help during the research.

\section{Conclusion}

The research result is presented in the form of learning model of happiness by using ASSURE as the research 's learning model comprises analyzing the students, formulating the specific learning objectives, selecting the method, media, and the learning materials, utilizing the media and learning materials, asking for responses from students, and evaluating. Moreover, the implementation of learning model of happiness had been done to the students of France Education Study Program who took Litterature Française as one of the course of the semester. Results show that students are interested in the theme of happiness delivered by the lecturer. They understand the theme, character, setting, and moral value in seeking for happiness that are told throughout the plot of the story. Besides, the respondents also create self-reflection about the condition of self-happiness and other things that can trigger or improve the level of happiness.

\section{REFERENCES}

Djojosuroto, K. (2006). Analisis Teks Sastra dan Pengajarannya. Yogyakarta: Penerbit Pustaka. Fananie, Z. (2001). Telaah Sastra. Surakarta: Muhammadiyah University Press.

Gilpin, J.M. (2008). Teaching Happiness: The Role of Positive Psychology in the Classroom. Pell Scholars and Senior Theses. Paper 24. http://digitalcommons.salve.edu/pell theses/24 Haryadi. (2014). Gangguan Psikis Tokoh-tokoh dalam Novel-novel karya Iwan Simatupang (Sebuah Kajian Psikoanalisis). Disertasi UniversitasNegeri Jakarta.

Hassanzadeh, R., \& Mahdinejad, G. (2015). Relationship between Happiness and Achievement Motivation: A Case of University Students. Journal of Elementary Education, 23(1), 5365. Retrieved from http://pu.edu.pk/home/ journal/36/V_23_No_1_\%202013.html.

Layard, R. (2007). Happiness and the teaching of values. Centrepiece, 12 (1). 18-23.

Nurgiyantoro, B. (2007). Teori Pengkajian Fiksi. Yogyakarta: Gadjah Mada University Press. Noddings, N. (2003). Happiness and School. Cambridge: Cambridge University Press.

Rijavec, M. (2015). Should Happiness Be Taught in School? Croatian Journal of Education, 17(1), 229-240. doi: 10.15516/cje.v17i0.1487

Rocher, J. (2000).Une saison indonésienne: Roman. Paris: Kailash éditon Seligman, M.E.P. (2002). Authentic happiness: Using the New positive Psychology to Realize Your Potential for Lasting Fulfillment. New York: Free Press. 